\title{
Indigenous and popular Islamic therapies of restoring health and countering sorcery among the Digo of Kenya
}

\author{
Hassan Juma Ndzovu \\ Moi University, Kenya. \\ Accepted 01 July, 2013
}

\begin{abstract}
Among the Digo of Kenya the belief and fear of sorcery is most prevalent that many things are explained in relation with it. Over the years, major sorcery-detection and eradication 'crusades' conducted by individuals alleging to be endowed with supernatural powers to detect and neutralize purported sorcerers have been witnessed among the Digo. During the eradication 'crusades' a considerable amount of money is collected to pay for the services of the presumed experts, indicating how serious the problem is regarded in Digo region. Islam is the religion of majority of the Digo, which has influenced their thinking and world-view, and has specific teachings on the practice of sorcery. Despite substantial influence of Islam on the Digo, the people continue to belief and practice sorcery leading to the development of popular religious therapy. This article will demonstrate that popular Islamic rituals and talismans have been adopted by the Digo to assist the traditional healers in countering the forces of sorcery as a means to restoring health to individuals and the general wellbeing of society. In exploring the practice of sorcery as experienced by the Digo, this article demonstrates how the traditional techniques of countering sorcery are rooted in the indigenous belief system of the Digo. Both the traditional and the popular Islamic approaches of countering sorcery reveal the ability of the different world views in making remedies and medicines for the victims.
\end{abstract}

Key words: Witchcraft, Sorcery, Islam, Digo and Magic

\section{INTRODUCTION}

Evans-Pritchard's (1937) study, Witchcraft, Oracles, and Magic Among the Azande, continue to influence the study of witchcraft and sorcery in Africa. This classical ethnographic study of Pritchard has mapped out the path for future studies on witchcraft and sorcery as he clearly defined the two practices, identified causes and central questions relating to the practices in Africa. Though scholarly interests on the function of witchcraft and sorcery in African societies have become robust thereby generating enormous volume of literature on the subject; this is not without limitations. Among the Digo of Kenya the belief and fear of witchcraft and sorcery is prevalent that virtually most occurrences are attributed to these forces. From the timeless beginning magic is a social behaviour related to people in varying historical periods. With its involvement of the supernatural power, magic has closely been associated with religion eliciting divergent views on the relationship of the two entities. Frazer (1963) and William and Vogt (1979) tend to perceive all phenomena involving the supernatural as divided into two categories of magic and religion. Together, they argue that religion makes supplication to the supernatural, whereas magic practitioners resort to manipulation of the supernatural to obtain certain ends. 
However, some contemporary anthropologists consider this dichotomy between religion and magic to be rather absurd, arguing that magic and religion should not be treated as exclusive entities, but they should be classified as magico-religious phenomena. The proponents of this position assert that magic and religion are part of human behaviour where both make an appeal to the supernatural world for help, guidance, and comfort.

As part of my M.Phil study a field research was conducted in 1997 to study the practice of witchcraft and sorcery among the Digo, and assess the influence of Islam on the practice. ${ }^{1}$ The concepts were described by analyzing the data collected from libraries, Kenya National Archives, and the field. People's views were analyzed, evaluated and any useful contributions were assessed. A considerable number of people were interviewed and they included elderly people, medicine men, diviners and alleged sorcerers who had information on the subject, sorcery. A cross-section of the Digo people were interviewed to divulge information that was used to assess the sociological aspect of the practices, and how in their opinion they thought Islam have influenced these practices. The knowledge of sheikhs, imams and madrassa teachers was also sought to give their views on the position of Islam on sorcery, and how this is related to the continuation of the practice in Digo land.

The Digo sub ethnic group is one of the nine sub-ethnic groups of the Mijikenda found in the south coast of Kenya. $^{2}$ Though the Digo have got several beliefs and practices that are common to the other Mijikenda subethnic groups, there are also conspicuous differences peculiar to each sub ethnic group. The Digo are believed to have migrated from Shingwaya, supposedly located between north of Pate Islands and south of Somali coast, and moved to their present territory in the late 15th century. The main cause of the migration was due to the hostility from their Galla (Orma) neighbours. ${ }^{3}$ From Shingwaya the Digo were led out by their leader Digore, from whom the community derived its name. ${ }^{4}$ In their south-ward movement, they established a settlement near Shimba-hills that later came to be known as kaya Digo or kaya Kwale. Originally, the kaya were fortified villages surrounded by thick forests for protection, which over time the forests assumed the name of the kaya. Within these forests, respected and dignified men and women of the community were buried in the precincts of the original kaya. This explains why the clearing of the

\footnotetext{
${ }^{1}$ This article is extracted from my M.Phil dissertation, 'The Impact of Islam on Witchcraft and Sorcery among the Adigo, Kenya', (Moi University, Kenya: 1999)

${ }^{2}$ The term Mijikenda refers to the nine sub-ethnic groups that include the Rabai, Chonyi, Giriama, Digo, Duruma, Jibana, Kauma, Ribe and Kambe.

${ }^{3}$ See Kenya National Archives, 'Native Tribes and their customs', Vol.I, Part 11, Coast Province.

${ }^{4}$ Kenya National Archives, 'Native Tribes and their customs', Vol.I, Part 1l, Coast Province. However, other writers have claimed the leader to have been Nyuni wa Mwavyoni. See, Kwale District Political Records, Vol.I, 1918-28, by Hon. C.C.F. Dundas.
}

forests in which the original kaya was built is considered a taboo because apart from being a resting place of their ancestors (koma), the Digo fingo (magico-religious substance) and herbs of important medicinal values are found in these forests. Brantley (1979) observed that 'as the storehouse of all medicines and the burial ground of the ancestors, the kaya became sacred.'

The buried fingo within the kaya (fortified villages) served as a ritual symbol, which the community prayed for blessings, good health, protection and sometimes rain. It is alleged that as part of the installation ritual, some people were buried alive on the spot where the magico-religious substance was to be placed. It is alleged that during the establishment of kaya Kinondo, seven people from the maternal side of the founders of the homestead were buried alive. ${ }^{5}$ Such identified spots are considered sacred and people are admonished to step on them for the consequence could either lead to one getting paralyzed or even dying. Allegedly, whenever one stepped on these 'sacred' spots, a terrifying scream made by the individuals who were buried-alive would be heard. As a magico-religious substance, the fingo protected the kaya against any possible evil, whether visible or hidden. Like any other holy places, certain taboos are observed to allow one getting closer to the fingo, evidently during worship or communal festivals. One of the most important condition requires that the individual should be married; and if she is married but from outside (different ethnic group)), she would not be permitted in the vicinity of the fingo if established that she had not stayed in the community for more than one year. This implied she is still being regarded as a 'stranger', who cannot be shown the secrets of the community. More so, a woman experiencing menstrual flow is forbidden to step or even go near the confines of the sacred ground, just as any person who did not take a bath after sexual cohabitation was not be permitted to get within the surrounding area of the revered place. ${ }^{6}$

By 1700 the Digo were well established in their coastal hinterland, actively participating in trade with the people at the lower coast. Arguably, the Digo are regarded as the first people from the coastal hinterland to have initiated trading ties with the residents of the lower coast, particularly Mombasa. ${ }^{7}$ To cater for this flourishing trade, it necessitated and facilitated the need to establish other fortified villages, which led to the appearance of subsequent kaya such as Kaya Tiwi, Kaya Kinondo, Kaya Muhaka, Kaya Diani, Kaya Dzombo and Kaya Waa. However, all these fortified villages did not emerge at

\footnotetext{
${ }^{5}$ Interview with Abadallah Mnyenze of Kaya Kinondo, aged 55, on 26/10/96. The names of the people who were buried alive include: i) Mwakatsiku, ii)Mwafaida, iii) Mwakombe, iv) Nkatsiku, v)Nfaida, vi) Nchisi, vii) Nravu. ${ }^{6}$ Interview with Bakari Kugula of Kaya Waa, aged 58, on 24/10/96; Said Mwagumbo Rimo of Kaya Ukunda, aged about 100, on 25/10/96; Mohamed mwataruma, of Kaya Muhaka, aged 60, on 25/10/96 among others.

${ }^{7}$ Bergman Jeanne. L, 'A Symbol, Spirit and Social Organization: A Comparative Study of Islam and Indigenous Religion among Two Mijikenda People' (University of Nairobi, Seminar Paper No. 182. 1988), 8.
} 
once, but came into existence over a period of time influenced by prevailing conditions. Each fortified village was independent and provided a significant representation of both the social and cosmological order, which began losing control over their people with the introduction the British colonial administration. ${ }^{8}$ Perhaps, due to the dislocation of the indigenous social structures, sorcery accusation intensified as a means of coping with the confronting forces of new economies, demands of modernization and globalization. ${ }^{9}$ With colonial political structures, traditional authority shifted to the heads of specific homesteads, and people visited the original kaya only when misfortune befalls a family or person. The coalescence of these homesteads resulted in the development of villages, which is a typical situation of the Digo at the present.

Islam is a distinguishing feature of the Digo today and a detailed study of the development of Islam among them has been done by Sperling (1995). The process of Islamization was long and complex as there was multiplicity of factors that contributed to corresponding variety of individual cases of conversion. The Digo's attitude toward Islam has been characterized by tolerance in which immediate changes in one's personal life were not required. According to Sperling (1995) contacts between Muslims and non-Muslims Digo continued, as converts continued to participate in the ngambi (council of elders) and to follow other practices of the Digo tradition. The rate of conversion was rather slow suggesting people's unwillingness to accept Islam until around 1880s that the movement to 'new' faith began to gain momentum. ${ }^{10}$ As Islam is today associated with the Digo identity there have surfaced among them zealous individuals who enjoin their kinfolks to 'pure' Islam, encouraging other Digo to negate traditional customs they perceive as paganic. These zealous individuals advocate for the observance of what they regard as acceptable Islam and striving to associate with the universal Islamic identity.

Therefore, despite a continuous acknowledgment of the existence of the practice of sorcery among the Digo, there has been no elaborate academic research on the subject. In this respect this study will add more data to the available generalized information on sorcery. Earlier studies on Digo's sorcery show major generalization that failed to accord the community a fair assessment to identify as a unique ethnic group. ${ }^{11}$ Therefore, my intervention in this article is to narrow down the subject

\footnotetext{
${ }^{8}$ Bergman, 'A Symbol, Spirit and Social Organization: A Comparative Study of Islam and Indigenous Religion among Two Mijikenda People', 15; David C.Sperling, 'Some Aspect of Islamization in East Africa with Particular Reference to the Adigo,' (Nairobi University, Seminar paper, 1970),102

${ }^{9}$ For connection between modernity, witchcraft and sorcery, see Peter Geschiere, The Modernity of Witchcraft, Politics and the Occult in Post Colonial Era (Virginia: University of Virginia Press, 1997)

${ }^{10}$ Sperling, 'Some Aspect of Islamization in East Africa with Particular Reference to the Adigo,', 6.

${ }^{11}$ Thomson Spear, The Kaya Complex: A History of The Mijikenda People of Kenya Coast to 1900 (Madison: University of Wisconsin, 1978); B.A. Ogot, Kenya before 1900 (Nairobi: East Africa Publishing House Ltd, 1986); Johnson
}

from that of the Mijikenda to the specific identified group, the Digo, and examine their practice of sorcery within the conventional structural-functionalist school of witchcraft studies. In addition, the article will explore the dual strategy of popular Islam and indigenous therapies observed by the Digo in reinstating health and confronting the diabolical forces of sorcery.

\section{THE INTUITIVE APPRECIATION OF THE DUAL ROLE OF SORCERY AS PRACTICED BY THE DIGO}

Despite the fact that witchcraft and sorcery are subjects that extensive studies have been done by scholars, opinions vary as to the correct definition of these practices. A close scrutiny of the existing study on witchcraft and sorcery shows that there are differences in definitions leading to some confusion. In his classical study among the Azande of East Africa, Pritchard posited:

The difference between a sorcerer and a witch is that the former uses the technique of magic and derives power from medicines, while the latter acts without rites and spells and uses hereditary psycho-psychical powers to attain his ends (Evans-Pritchard, 1937: 367).

Clearly, witchcraft and sorcery have a common goal of causing harm, though their mode of operation differs, where witches allegedly inflict harm through a hereditary, inherent power that they possess without employing any 'evil medicine' or poison. As a result Pritchard concluded that "witchcraft is a psychic act (Evans-Pritchard, 1937: 21)." On sorcery, Pritchard observed that sorcerers harm their supposed 'enemies' by applying rites, spells and incantation to a specific individual (presumed enemy). Pritchard's study is of great value and future scholars adopted his distinction in relation to the people they studied. However, Shorter (1974: 103) is critical of the distinction made between witchcraft and sorcery, arguing that the division is merely theoretical and cannot be applied to some societies. He observed that some of the communities he had studied are unable to distinguish between the two practices since witches are also thought to be sorcerers. Nevertheless, my definition of sorcery that corresponds to my personal experiences of the practice among the Digo, is similar to the one propounded by Pritchard, which is the employment of evil powers through the use of tangible materials and appropriate procedure to destroy property or harm others.

Among the Digo, there is a profound and pervasive belief in magic (uganga), which they utilize in most facet of their lives. In Digo's world view uganga is hold as a neutral power, which can be either good or evil depending on the use, and when employed selfishly to

A. Mwangudza, Kenya's People: Mijikenda. (London: Evans Brothers Limited, 1983). 
procure peoples' advantage or attack their victims, it is bad. It is this bad magic that is referred to as sorcery. On the other hand, when used for the well-being of members of a community, it is a necessary protection against the destructive activities of evil people, thereby good. This good magic is the one that is commonly declared as uganga. In procuring the welfare of the society, uganga is employed as protection against outward happenings; immunity against machete cuts; in assuring successful harvest; in enabling good sale and also against the perpetrators of evil (the sorcerers). During hostilities, persons with magic of invulnerability are likely to overcome fear and fought to heroism much more easily than the persons who faced danger without such magical support. ${ }^{12}$

In Digo society, sorcery (utsai) connotes to maligning activities attributed to individuals who employ objects and incantations to manipulate supernatural powers to harm others or destroy properties. Traditionally, the community strongly condemned the malicious use of sorcery, but socially accepted and considered it necessary when employed for revenge and retaliation purposes. This implied that it was the intention in the usage of sorcery and not its mere possession that was immoral. This idea reflects the Digo intuitive appreciation of the dual role of utsai - useful to the society on the one hand and antisocial on the other. During the earliest period (the kaya age) sorcery was an important skill and necessary knowledge in society, which made it a sort of a prerequisite for each Digo clan that wanted to be feared, respected and recognized to have a sorcerer (sing. mtsai, pl. atsai) among them. From the Digo's interpretation this was necessary because the protector of the clan should possess sorcery, which was seen as a source of power and a means of social control. However, despite this noble intention the usage of utsai for retaliation and revenge, or harm an individual even when the victim is a presumed enemy is an evil usage. Having acquired the 'black' magic connotation, sorcery among the Digo involves anti-social employment of mystical powers thereby perceived as a source of evil. Hardly anything happens to a Digo without being attributed to the power of utsai. To them, sorcery causes serious and protracted illness, unusual malady, it kills, causes misfortune, impotency and accident not apparently the result of the victims carelessness, creates disharmony, and anything extraordinary that brings with it bewilderment. ${ }^{13}$

It is common for kinsmen and friends among the Digo to accuse each other sorcery whenever misfortune befall the other. Families, irrespective of their structures,

\footnotetext{
${ }^{12}$ Interview with Muhammad Mwataruma of Muhaka, aged 60, on 25/10/96; Salim Muhammed Mbogi of Mwabungo, aged 63, on 27/10/96; Mwachitsanga wa Mwadama of Jeza, aged about 70, on 22/10/96.See also Daily Nation, Saturday, September 13, 1997, p.3; East Africa Standard, Saturday, September, 13, 1993, p.3.

${ }^{13}$ Interview with Muhammad Mwataruma of Muhaka, aged 60, on 25/10/96; Interview with Mwachitsanga wa Mwadama of Jeza, aged about 70, on 22/10/96.
}

whether polygamous or monogamous, are centers of sorcery accusation among siblings driven by jealousies and competition. Such accusations serve to explain the calamity and pinpoint blame for it as exterior. Some analysts argue that science has failed to deliver responses that are psychologically sustaining when people interrogate the reasons behind happenings. This explains why some Digo turn to sorcery accusations in search of answers that science is unable to offer. But rather than resolving the presumed maladies, accusations tend to weaken group solidarity, escalating conflict among families and neighbors. Similar to Geschiere (1997) observation, two contradictory themes emerge in sorcery accusation among the Digo. First is the idea that people are successful in whatever field through sorcery, and the perception that the fear of sorcery removes inequalities by encouraging sharing, simplistic living and humility so as not to arouse jealous from the less fortunate. In these contradictory notions, the insinuation is that sorcery on the one hand increases inequality, and on the other because of fear of its power it decreases inequality.

There are different types of utsai that Digo sorcerers can employ to cause specific problem or illness to their victims. These include mkomo that causes body paralysis; mbayu mbayu associated with insanity where the victim behaves abnormally; chivuri attributed to blindness; tzaiko famous for perpetrating hysteria; tego known for inflicting chronic sexual disease and a host of others. In making any of these types effective, sorcerers have several ways of magically harming their enemies, which include using items that belong to their victim. This illustrates why in Digo society people fear to carelessly leave their hair, nails, clothes and other items that had been in direct contact with them. This is based on the idea that things once in contact remain forever in contact even when the contact is severed (Frazer, 1963: 49). Allegedly, sorcerers can utilize these items to harm people, by depositing them in a shell and leave it in a panga (mostly thought to be a devil's shrine) where a sorcerer will concoct (kukokotera) and appeal to the evil spirits to injure the targeted person by either becoming ill, or even dying. ${ }^{14}$ This form of magic, Frazer (1963: 49) describes as 'contagious magic', which among the Digo also includes using the victim's footprints. In this case a sorcerer takes some sand in the victim's footprint and mixes it with specific magical formulae while invoking evil to befall the targeted person, which supposedly the individual begins to complain of numerous problems. ${ }^{15}$ In this regard, some Digo carefully destroy or dump in toilet all items that had once been in contact with them as a way of ensuring that an evil person does not have access to them. Frazer's (1963: 16) 'homeopathic magic'

\footnotetext{
${ }^{14}$ Interview with Mwanasha Bakari of Msambweni, aged about 90, on 21/10/96; Abdallah Mwangandani of Vyongwani, aged 65, on 27/10/96; and Salim Muhammed Mbogi of Mwabungo, aged 63, on 27/10/96.

${ }^{15}$ Interview with Juma J. Mwamaneno of Vyongwani, aged about 100, on 27/10/96
} 
category or imitative magic, which denotes what happens to an object that looks like another will affect the latter, is also evident among the Digo. The Digo's imitative magic is referred as kualwa chikowa, which literally implies destroying one's shadow or 'spirit' allegedly done through the use of water that serves as a mirror. With water in a container, a sorcerer performs mystical acts that results in the appearance of the image of the 'enemy', which is pierced by a sharp object leading to the individual to be harmed accordingly. ${ }^{16}$

Through either non-genetically inheritance or purchase, the knowledge of sorcery has been passed down from one generation to the next. In the case of inheritance, sorcery is acquired by an individual inheriting the paraphernalia associated with it from a relative. Like acquiring property, mostly the maternal relatives (kuchetuni) who are traditionally close to a person, are the ones likely to inherit these powers (Hassan, 1992: 107-110). Nevertheless, for others who do not have a close relative to pass the skill to them, gain the knowledge of sorcery by purchasing it. In such instances, a prospective client pays a very cheap fee, making it possible for anyone to procure it. While it is widely held that anybody is a potential enemy to sorcerers, this does not rule out the possibility of jealousy as in some people sought the assistance of sorcerers against affluent members in society. In instances, where sorcerers maliciously harm their victims, demonstrates power giving them the "untouchable" status in the community alluring in an ambiguous way, fear, respect and hatred. ${ }^{17}$ Such perception of sorcery explains why the moment some Digo experiences misfortunes, they consider those who are likely to hate them due to the conviction that there are other people whose pleasure is to see them suffering and are displeased at their good fortune. Evans-Pritchard (1937: 100-101) describes a similar thought among the Azande arguing that in this society people are aware that if they become "rich the poor will hate" them and that if they prosper in "social position" their "inferiors will be jealous" of their authority or even when they are talented in anyway, the less gifted will approach them with malice. Ironically, people who believe that others are jealous of them will not take any measures, but would continue to be polite and understanding to their presumed enemies. Nonetheless, once these people suffer misfortunes they would quickly assume that one of their supposed enemies have used sorcery against them. This demonstrates that sorcery in the Digo society operates where there is social tension a situation comparable to the Ibibio of Nigeria (Offiong, 1991: 87).

During the earliest period of the kaya settlement, sorcery was an instrument dominated by male used for

\footnotetext{
${ }^{16}$ Interview with Mwanamgeni Bakari of Vingujini, aged about 55, on 21/10/96; Mwachitsanga wa Mwadama of Jeza, aged about 70, on 22/10/96, and Abdallah Mnyenze of Kinondo, aged 55, on 27/10/96.

${ }^{17}$ This view was evident during the informal conversations I had with the people.
}

exerting power and authority in the community. Gradually, women began becoming experts in sorcery presumably to escape male domination, and as a result sorcery became a matter of preference for both sexes. Sorcerers among the Digo are normal people who live like any ordinary persons, and sometimes occupy influential positions in the society. Clearly, sorcery in the Digo community cannot be attributed to specific families or clan, or class, but every individual in society is capable of becoming a sorcerer.

\section{IS SORCERY A REALITY OR FALLACY? AN ISLAMIC VIEW}

A scrutiny of the Qur'an shows that the term magic, witchcraft and sorcery are used interchangeably to refer to the same thing. ${ }^{18}$ This could be attributed to the problem of translation as there are no English equivalents to suit the original Arabic word sihr, which is popularly used to refer to all activities employing mystical powers (Lewis, 1966: 60; Philips, 1994). Within the Qur'an the practice of sorcery is not explained in detail, and its operational mode not clearly stated apart from the effects it causes, which include harming, cause illness and bringing disharmony (Tabatabai, 1988: 8; Al-Qaradawi, 1989: 243). ${ }^{19}$ The evil practices that people do are explained in Islam as necessary due to the dual nature of human's soul (nafs) expounded in the state of nafs-tulmutmaina, when the soul is inclined towards the righteous deed, and nafs-tul-ammara, when it is inclined towards evils. ${ }^{20}$ It is the later stage of the human soul, the rebellious soul, which is alleged to be easily misled as it is inclined toward evil that include observing sihr, which is considered as challenging the divine authority. As the rebellious soul challenges divine authority, it is explained by some Muslim jurists to be under the influence of iblis (Satan) and his agents, in the form of fallen Jinn, who are hold to be the source of magic, divination, and sorcery (Anderson, 1990: 27). Consequently, any form of magic, good or bad, is considered forbidden in Islam since it is perceived as an attempt to prevail over the will of God.

Even though the Qur'an has devoted a whole chapter (al-Jinn) describing the world of jinn, still some people tend to deny the reality of their existence. According to the Qur'an jinn represent another form of God's creation presumed to be hidden from the ordinary eyes of humankind ((Philips, 1994: 75-76). ${ }^{21}$ Generally, it is demonstrated in the Qur'an that jinn can be classified into two categories in relation to their faith, Muslims

\footnotetext{
${ }^{18}$ See Qur'an 2:102, 10:81, 20:69-71, and 113:4. Also compare the translation of M.H. Shakir in Holy Qur'an, and Holy Qur'an: English Translation of Meanings and Commentary.

${ }^{19}$ Qur'an 2:102.

${ }^{20}$ See commentaries by Yusuf Ali, The Holy Qur'an: English Translation of the Meaning and Commentary (Medinah: The King Fahd Holy Qur'an Printing Complex), for both suratul Qiyamat (75) and A-Fajr (89).

${ }^{21}$ Qur'an 15: 26-27.
} 
(believers) and kafir (disbelievers), and it is the disbelieving jinn who are denoted in the Qur'an by various names like ifreet, shaitan and qareen, which could translated as demons, devils, 'spirits', ghosts among others (Philips, 1994: 78). ${ }^{22}$ Though the jinn are by nature mysterious and hidden, there is a popular belief that it is possible for people to capture and control jinn for various purposes. Allegedly, among other errands during the 'controlling' moment it is possible for jinn to assist their human 'partners' in performing magic, divination, and sorcery. Clearly, this view demonstrates that jinn are the main actors and source behind the power of sorcery, and therefore, the moment one is able to comprehend the world of jinn, all the supernatural and mystical incidences could easily be explained.

A popular narrative in Islam posits that there existed people in history who had knowledge of sihr, which they ascribed its origin to Prophet Suleiman, proclaiming he owed his kingdom and extraordinary powers to it. ${ }^{23}$ However, commentators of the Qur'an argue that God refutes this association of sihr with Suleiman, assigning the genesis of sihr to the two angels, Harut and Marut. ${ }^{24}$ Purportedly, the two angels appeared in human guise to test the faith of Israelites captives in Babylon by offering to teach them the knowledge of sihr. As they embarked in teaching sihr they supposedly warned the people, "We are holding out these temptations merely for your trial. You should not, therefore, ruin your life here and in the hereafter by asking and taking help from this 'science.",25 Though narrative is ambiguous, this opinion of the Qur'an clearly informs us that Muslims are aware of the existence of the forces of sorcery. Despite the Qur'an's acknowledgment of its existence, Muslims are expected not to practice it, as it is assumed to cause harm and disharmony in the social order of the society.

The earliest mention of sorcery in Qur'an is that expounded on the paradox of Prophet Musa (Moses) and an ancient Egyptian King, the Pharaoh. This is paradox, which recognizes the reality of magical powers in the acts of Pharaoh's sorcerers together with their snakes, and Musa's own ability to perform powerful 'magical' wonders to undo those of the King's sorcerers. ${ }^{26}$ The Qur'an dismisses the Egyptian sorcery as mere 'superstition' and falsehood, in reference to the snakes presented by the Pharaoh's sorcerers that were swallowed by Musa's rod, turned to a snake. ${ }^{27}$ The Qur'an contends that whatever the people saw as snakes in the hands of the Pharaoh's sorcerers was not reality, but illusionary images thought to be real after the sorcerers had 'bewitched. ${ }^{28}$ Some analysts have related this experience to be similar to the

\footnotetext{
${ }^{22}$ Qur'an 72: 1-4; 14-15

${ }^{23}$ S. Abula'la Maududi, The Meaning of the Quran: Part I (Nairobi: Islamic Foundation, 1977), 92

${ }^{24}$ Qur'an 2:102

${ }^{25}$ As quoted by Maududi, The Meaning of the Quran: Part I, 93

${ }^{26}$ Quran 7: 117

${ }^{27}$ Quran 7: 117

${ }^{28}$ Qur'an 7:116
}

activities of tricksters who perform wonderful acts that appear to be tangible, but in reality they are not. They argue that it is through the aid of the evil jinn that the sorcerers and tricksters are able to influence people to view their activities as real and efficacious (Ebrahim, 1973: 8). Nevertheless, even though the power of Pharaoh's sorcerers was portrayed to be inferior to that of Musa, the reality of their power was assumed. The portrayal of sorcery as being effective is expounded by an Islamic tradition that informs of Prophet Muhammad being harmed by a Jewish sorcerer, and only the timely warning by Jibreel disclosed the hidden spell, and consequently, God revealed surat Falaq to Muhammad to be used as a guard against sorcery (Idries, 1992: 82; Tabatabai, 1988: 8). ${ }^{29}$ This episode leaves one to ponder about the reality and power of sorcery. Is dismissing the practice as superstition is plausible? ${ }^{30}$ Even though Islam categorically prohibits sihr, this has not successful translated into resolving cases of sorcery among the Digo.

\section{TREATMENT AND 'MEDICATION' AGAINST SORCERY: INDIGENOUS AND POPULAR ISLAMIC REMEDIES}

From the pre-colonial period to the present day Kenya, the Digo have been known to be working tirelessly to curb sorcery. Indeed, efforts of these people in dealing with sorcery can be viewed at two levels; (i) individually and (ii) collectively. Individually, families or persons may seek assistance from traditional specialists once they realize that the problems they are experiencing have been 'influenced' by a sorcerer. On the other hand, when the 'sorcerers' effect is felt by the entire village, they collectively invite the traditional specialists to assist them in resolving the problem. In most cases, traditional medicine-men (aganga) are employed to supply protective objects or medicines, and in this respect charms, amulets, (irizi or chiphogo), medicine drunk or rubbed into the body (vuo), and many other secret and open precaution are used by the community to instill the feeling of safety, protection and assurance. This appears to suggest that the activities of the aganga are mainly based on stabilizing good fortune (restoring health) and countering misfortune. Once it is established that a sorcerer is responsible for a certain misfortune, the aganga will attempt to neutralize the diabolical power and to prevent future attack.

\footnotetext{
${ }^{29}$ Qur'an, 113: 1-4.

${ }^{30}$ For more on sorcery in the Qur'an see Qur'an 20:69, 10:81, and 2:102. See also the hadith of Prophet Muhammad on magic and sorcery as reported by Abu Huraira: "Abstain from seven deadly sins; (1) to ascribe to divinity anything besides God: (2) to practice magic and sorcery; (3) to commit murder; (4) to take usury; (5) to devour an orphan's property; (6) to run away from the battle field in Jihad; (7) to accuse virtuous and chaste women of adultery. (Burkhari, Muslim)", in Syed Athar Hussein, The Book of Thousands Lights. (Lucknow: Lucknow Publishing House, 1975), 26.
} 
The role of a medicine man is significant in the traditional life of some Digo, such that whenever something goes wrong in the life of an individual or family, the affected people would usually first resort to medicine men for help and advice. Due to the trust people have in them, it is clear that they serve as doctors and advisers. In most cases, when people realize that there are misfortunes or problems they initially consult a diviner (mpiga mburuga) to diagnose the nature and cause of the adversity. Generally, there are diviners who practice both divination and healing, and once the problem is established the medicine man or diviner treats the symptoms and the attendant misfortunes. During the treatment the client might have two purposes; i) to know the origin of the misfortune, and ii) to counter the source of evil. In case of the latter, the client might intend to inflict sufferings on the offender or seize the offender's life or neutralize the evil powers by sending curses through the assistance of the medicine-man. ${ }^{31}$

In delivering their services to the people, the medicine men provide assistance in form of charms, amulets and incision (ndembo) on the body thereby using their powers or expertise to protect homes, families and their properties. It is common that when one visits some Digo homes or business premises, one might see amulet(s) hanging on the door or on the roof top of the house or one might hear that within the compound of a certain home there is a fingo (magico-religious substance) that has been buried ${ }^{32}$ or when one comes across some Digo children, one would notice that they have amulets (irizi or chiphogo) either around their necks, waist or wrist. Together with other articles and magical immunization of the people, all these are seen as efforts to provide protective measures against the evil powers of sorcery. The most frequently used immunization is the black powder, muhaso, which is made to work when incision is made on different places of the client's body. And while blood is still gushing out, the powder is rubbed into the wounds, inoculating the individual, and leaving indelible marks on the skin, which are evident in most Digo, whether traditional or practicing Muslim. It is widely held by those who observe this practice that the powder produces an anti-dote that prevents sorcerers from harming the individual. On the other hand, the buried fingo, serving as a protective charm, is assumed to fight back all sort of evil sent to an individual. ${ }^{33}$

Like other Muslims, Digo are also expected to relate their actions with the Qur'an since it is the final authority for all believers. Based on Qur'an 17:82, "We have revealed 'in' the Qur'an that which is a healing and mercy to the believers", there is a strong conviction among them

\footnotetext{
${ }^{31}$ Interview with a witch-hunter Ngome wa Vyoni.

${ }^{32}$ The fingo buried in the individual homes is different from the one found in the ancestral kaya. Though the fingo concept is borrowed from the traditional kaya, the fingo found in an individual home serves as a protective charm for a specific home.

${ }^{33}$ This was the view of most of the informants.
}

that the Qur'an has solutions to all their problems and misfortunes. Deducing from the foregoing verse, some commentators of the Qur'an have argued for its ability to heal physical diseases, cure errors, ignorance and doubt. Due to its presupposed power, Muslims have applied various verses and chapters of the Qur'an to counter sorcery, particularly chapters Yasin and the Muawadhitan (surah 113 and 114) together with other verses as helpful incantations (Trimingham, 1964: 120). This belief has encouraged Muslims to constantly recite those chapters or verses of the Qur'an alleged to be efficacious in warding off evil. This practice was emboldened during Prophet Muhammad's era and spread to other regions when other communities embraced Islam.

There is a popular opinion among Muslims that Muhammad encouraged recitation of specific portion of the Qur'an suitable for healing, but problem appeared when a section of the population, especially the minors, were unable to recite the Qur'an thereby demanding for innovative means of protecting them. As a genius way of guarding them from the forces of evil, the wearing of Qur'anic text amulets (anzima) was developed (Abdurrrahman, 1989: 395). Gradually, the practice became popular in various Muslim societies where people began wearing Qur'anic text amulets to secure themselves from evil, including sorcery. Because of associating the practice of consulting traditional medicine men with paganism, some Digo Muslims would be comfortable in accessing a maalim (a Muslim cleric who sometimes serve as medicine-man with the Islamic tradition) to prepare Qur'anic amulets for them. These amulets are either encased in a leather or metal sachet that is worn by the client as prescribed by the maalim who instructs the individual how and where the amulet is to be worn. The types of amulets made are those for preventive and curative nature, whose efficacy lies in the conviction that the power inherent in the verse of the Qur'an can be transferred to the objects and eventually to the people wearing them (Trimingham, 1986: 84). These amulets together with the recitation of specific verses of the Qur'an forms a way of seeking refuge in God in order to protect and restore health, just in the same way medicine is taken for that purpose.

In tracing the practice of preparing Qur'anic amulets in the earliest Muslim's history, a hadith of Muhammad as recorded by Imam Malik Ibin Anas posit:

Humayd Bin Qays Al-Makki said, 'A man came to the messenger of Allah with the two sons of Jafar Bin Abi Talib. He said to their nurse-maid 'Why are they so thin?' Their nurse maid said, 'Messenger of Allah, the evil eye goes quickly to them. Nothing stops us from asking someone to make talismans (using ayahs of Quran) for them, except that we do not know which of that would agree with you.' The messenger of Allah said, 'Make talismans for them. Had anything been able to precede the decree, the evil eye would precede it.' (Abdurrrahman, 1989: 395) 
The above hadith is presented as proof to illustrate that Muhammad sanctioned the making of Qur'anic amulets in warding off magical evil including sorcery provided the right procedures were adhered. Consequently, some Digo maalims like maalim Muhammed Hussein Kilalo, maalim Athman Sharif among others have used this argument has their basis for preparing Qur'anic amulets to their clients to protect and 'heal' them against sorcery. Nevertheless, another hadith, reported by lbin Masud and Jabir, contends that Muhammad disliked the practice of making charms that he associated to shaitan's work, thereby presenting a divergent view on a practice that is popular among Muslims (As-Suyuti, 1994). Even among maalims who accept the production of Qur'anic amulets, there are conflicting opinions as to what is the correct practice of making the amulets. Some of the maalims are of the judgment that apart from verses and chapters of the Qur'an, the names of angels, certain jinn, mysterious formulas and symbols can be incorporated to make an amulet more effective (Anderson, 1990: 35). ${ }^{34}$ This is because these elements have mystical powers that can be tapped and utilized in countering sorcery, a view that appear to advocate the application of 'white' magic in warding off sorcery. It is in white magic where the additional elements are introduced, bringing the Muslims in Digo land to a yet another debatable issue of whether this form of magic is halal (permissible) or haram (forbidden) in Islam.

Contrary to this, other maalim have rejected the adoption of the additional elements in preparing Qur'anic amulets, asserting that it is bidaa (innovation). ${ }^{35}$ They argue the additional elements would confuse Muslim to think that they are significant in supporting the accepted 'healing' verses to be efficacious. It is this addition that makes the opposing group of maalim in Digo land to differ with the earlier group, declaring 'purely' Qur'anic anzima as halal, a view represented by Qayyim-al Jauziya, who argues:

Although we find examples of treatment of illness through amulets and prayers, it is severely restrained. It is reported that the Prophet had at first forbidden all amulets for fear they contained certain words that compromised the rigorous monotheism of the Qur'an by involving spirits and other powers. Subsequently, he allowed their use but only if their contents were in accordance with the teaching of the Qur'an and preferably based upon Qur'anic prayers (Rahman, 1987: 34).

Clearly, it shows that right from the beginning Muhammad

\footnotetext{
${ }^{34}$ Interview with maalim Muhammed Hussein Kilalo of Mwaembe, aged about 60, on 3/11/96, and maalim Athaman Sharif of Golini, aged 50, on 22/11/96. ${ }^{35}$ Some of the sheikhs who reject the inclusion of other substances in the preparation of Qur'anic amulets include maalim Muhammed Bakari of Msambweni; sheikh Nassoro Konga of Waa; and sheikh Hassan Mwalupa of Matuga.
}

confronted the 'unacceptable' ways of making Qur'anic amulets that incorporated other mystical powers and formulas. This conflict on the acceptable and unacceptable Qur'anic amulets is an ongoing debate evident among Digo Muslims.

Another method, similar to the writing of the Qur'anic amulets used by maalim in Digoland to treat people affected by sorcery is the devising of kombe (chalice). While studying the Swahili, J.S. Trimingham noticed that maalim in that community concoct kombe, which is administered to people affected by the practitioner of evil (Trimingham, 1986: 123). And due to close proximity between the Digo and the Swahili this practice found its way among the former. Like the Swahili, Kombe among the Digo is considered as a sort of a holy medicinal liquid whose preparation involves writing verses or even a whole surat of the Qur'an with saffron on a plate. Thereafter, the plate is washed by rose water to be filled in a bottle that is then given to a patient to drink. Supposedly, kombe is assumed to be effective in warding off evil, thereby occasionally it can be rubbed over the body depending on the prescription of the maalim (AsSuyuti, 1994: 169). By virtue of it being derived from the verses of the Qur'an, no evil is expected to withstand its power, and as a consequence capable of ridding out possessive spirits, curing illness and rendering bad magic impotent. In some instances, depending with the nature of the problem, the maalim can recommend the making of both amulet and kombe, which together are regarded as popular Islamic approaches of restoring health and countering evil forces.

A more elaborate method employed by Digo Muslims, which is a also common among the Swahili community, in confronting the forces of sorcery is through applying the ritual of ahlal badr (people of badr), a liturgical incantation against any evil. Ahlal badr apparently incorporates Qur'anic passages, names of Muslims who participated in the battle of Badr and invoking the power of the angels whose intervention was decisive in assuring victory (Trimingham, 1986: 123). There is a popular opinion among Muslims that the people who took part in the battle of Badr have attained God's mercy and subsequently assured of a place in paradise. Because of their position, some jurists have deduced that soliciting their intervention as mediators, success against evil is guaranteed, giving impetus to the development of a ritual employed in countering, checking and diffusing sorcery. Some of the renowned maalim among the Digo considered knowledgeable in conducting the ahlal badr ritual, include Juma S. Majuto, maalim Hamza, Muhammad Hussein Kilalo and Kassim Abdallah Rangi who are admired and appreciated in the community because of their invaluable expertise in performing the ritual. Whenever the ritual is observed, the peoples' feeling and impression, either individually or as a community, is that they are now safe from the evil machinations of sorcerer who allegedly fear the power of ahlal badr, which is considered potent and efficacious. 
${ }^{36}$ Argubly, this ritual is an interaction between the living and the dead, particularly the heroes of the badr war. The recognition of the spirit of the dead as being powerful is the feature of the ahlal badr ritual that has split sheikhs in Digo land concerning the authenticity of the practice. Due to its concept of mediation, some sheikhs in Digo land have strongly challenged its validity, arguing that mediation is a form of shirk and thereby unacceptable in Islam. The foundation of this argument is derived from Qur'an 2:186 and 13:14-15, which the detractors uses to contend that Muslims are always expected to pray directly to God without relying on any form of intercession. Nevertheless, ahlal-badr has persisted among the Digo and is held as important and effective in countering the forces of sorcery.

\section{CONCLUSION}

The practice of sorcery is a source of various disharmonies and quarrels, and no anthropologist would deny this fact. According to the Digo, the practice is perceived as a source of illnesses, suffering, misfortunes, and miseries of all sorts, leading to the practitioners of this knowledge to be the most hated and feared people in the community. Therefore, it is the opinion of most Digos that the various sicknesses, deaths, accidents, tragedies, danger and unhappy mysteries that they encounter are caused by the use of this mystical power in the hands of sorcerers. Consequently, the Digo will do everything within their power to fight it. As a prevalent force, the Digo widely employ the indigenous remedies and approaches in tackling problems attributed to sorcery. However, by being Muslims, there are also cases when some Digo uses the sources and techniques of their new religion (Islam) to counter maladies caused by sorcery. With the arrival of Islam, different concepts and practices were deployed, thereby weakening indigenous religious ideas, including ideas on sorcery. The complicating presence of Islamic doctrines escalated negative feeling on sorcery, and disparaging indigenous form of remedies against the evil forces of sorcery. Despite some sheikhs' disapproval of the indigenous techniques, the people continue having faith with it, and together with the popular Islamic methods, the ability to make remedies and medicines for the victims is developed. It is a sort of religious therapy that gives people hope and 'heals' the afflicting problem.

\section{REFERENCES}

Abdurrrahman B (1989). Al-Muwatta of Imam Malik Ibn Anas: The first Formulation of Islamic Law. London: Kegan Paul International p.395. Ali, Yusuf, The Holy Qur'an: English Translation of the Meaning and Commentary. Medinah: The King Fahd Holy Qur'an Printing

\footnotetext{
${ }^{36}$ Interview with Maalim Muhammad Hussein Kilalo of Mwaemba, aged about 60, on 3/11/96; and Imam of Kwale Mosque, Omari Jilo, aged 36, on 22/11/96.
}

Complex.

Al-Qaradawi Y (1989), The Lawful and the Prohibited in Islam. Lagos: Al-Tawheed Publishing Company p.243.

Anderson N (1990). Islam in the Modern World: A Christian Perspective. England: Apollo p. 27, 35.

As-Suyuti Jalalud-Din A-R (1994). Medicine of the Prophet. London: Taha Publishers Ltd pp.169-172.

Awolalu JO, Dopamu PA (1979). West African Traditional Religion. Ibadan: Onibonnoje Press and Book Industries Ltd.

Brantley C (1979). 'An Historical Perspective of the Giriama and Witchcraft Control', Afr. J. Vol.49.

Caro J (1971). The World of Witches. Barojo: University, of Chicago Press.

Chidester D (1992), Religions of South Africa. New York: Routledge.

Crawford JR (1967). Witchcraft and Sorcery in Rhodesia. London: Oxford University Press.

Daily Nation, Saturday, September 13, 1997, p.3.

Dopamu PA (1977). 'The Practice of Magic and Medicine in Yoruba Traditional Religion,' Unpublished Ph.D. Thesis, University of Ibadan.

Dopamu, Peter Ade, (1979), 'Yoruba Magic and Medicine and their Relevance for Today,' A Journal of Nigerian Association for the Study of Religions, Vol. 4.

Dundas CCF, in Kwale District, Political Records, Vol. 1, 1918-28.

East Africa Standard, Monday, October 7, 1996, pp.1 and 7.

East Africa Standard, Saturday, September, 13, 1993, p.3.

Ebrahim M (1973). Wonders Acts, Magic and Sorcery. Karachi: Peer Trust p.8.

Evans-Pritchard EE (1937). Witchcraft, Oracles, and Magic among the Azande. Oxford: Claredon Press pp.21, 387, 100-101.

Forde D (1976). African Worlds: Studies in the Cosmological Ideas and Social Values of African Peoples. Oxford: Oxford University Press.

Frazer JG (1963). The Golden Bough: A Study in Magic and Religion. London: Macmillan \& Co. Ltd. pp.16, 49.

Geschiere P (1997). The Modernity of Witchcraft, Politics and the Occult in Post Colonial Era (Virginia: University of Virginia Press.

Gluckman M (1959). Custom and Conflict in Africa. Oxford: Basil Blackwell \& Mott Ltd.

Government of Kenya (1987). 'Kwale Social Cultural Profile.' Nairobi: University of Nairobi.

Hassan AM (1992). 'Impact of Customary law on the Practice of the Islamic law of Succession: A Case Study of the Adigo of Southern Coast of kenya,' (Unpublished M.A. Thesis, Nairobi University) pp.107-110.

Hussain A (1992). Beyond Islamic Fundamentalism: The Sociology of Faith and Action. Leicester: Volcano Press Ltd.

Hussein SA (1975). The Book of Thousands Lights. Lucknow: Lucknow Publishing House.

Idries S (1992). Oriental Magic. London: The Octagon Press p.82

Kayamba, Martin High on 'Notes on the Wadigo,' in Kwale District, Political Records 1:1918-28, p.278.

Kenya Times, Friday, October 11, 1996, p.25.

Kenyatta J (1989). Facing Mount Kenya. Nairobi: Heinemann.

Lewis IM (1966). Islam in Tropical Africa. London: Oxford University press, p.60.

Mahmudunnasir S (1984). Islam: Its Concept and History. New Delhi: Kitab Bhavan.

Mbiti JS (1969). African Religion and Philosophy. Nairobi: Heinemann Kenya Ltd

Mkangi K (1995). 'The Perception of Islam by Mijikenda of Kenya Coast,' in M. Bakari and Yahya S.S, Islam in Kenya. Nairobi: Signal Press Ltd.

O'dea TF, O'dea AJ (1983). The Sociology of Religion. New Jersey: Prentice Hall, Inc.

Offiong DA (1991), Witchcraft, Sorcery, Magic, and Social Order Among the Ibibio of Nigeria. Enugu: Fourth Dimension Publishing Co. Ltd, p. 87.

Parrinder G (1963). Witchcraft: European and African. London: Faber and Faber Limited.

Philips AAB (1994). The Fundamental of Tawheed: Islamic Monotheism. Riyadh: International Islamic Publishing House pp.7576, 78, 97.

Rahman F (1987). Health and Medicine in the Islamic Tradition. New 
York: The Cross Road Publishing Company p. 34.

Shorter A (1974). East African Societies. London: Routledge and Kegan Paul.

Siddiqi, Muhammad Iqbal (1981), Islam Forbids Intoxicants and Gambling. Lahore: Kazi Publications.

Sperling DC (1995). 'The Frontiers of Prophecy: Healing the Cosmos and Islam on East African Coast in the 19th Century,' in Revealing Prophets. London: James Currey Ltd.

Tabatabai AMH (1988). Tafsiri ya Al-Mizani: Juzuu Amma. England: The London Islamic Foundation p.8.
Trimingham JS (1964). Islam in East Africa. London: Oxford University Press p. 120.

Trimingham JS (1986). Influence of Islam in Africa. Singapore: Longman Publishers Ltd, p. 84, 123.

William L, Vogt E (1979). Reader in Comparative Religion: An Anthropological Approach. New York: Harper and Row Publishers. 